\title{
IMPLEMENTATION OF DEMOCRATIC LEADERSHIP STYLE AND TRANSFORMATIONAL HEAD OF MADRASAH IN IMPROVING THE QUALITY
}

\author{
Aulia Diana Devi'), Subiyantoro'2) \\ ${ }^{1}$ Universitas Islam Negeri Sunan Kalijaga Yogyakarta, Indonesia \\ email: auliadianadevi15@gmail.com \\ ${ }^{2}$ Universitas Islam Negeri Sunan Kalijaga Yogyakarta, Indonesia \\ email: subiyantorodr@gmail.com
}

\begin{abstract}
The management of educational institutions or organizations is a very important issue in the world of education. Because, the success of an educational institution depends on the leadership of the head of madrasah. This research aims to find out the implementation of democratic leadership style and transformational head of Madrasah in MAN 1 Tulang Bawang Barat Lampung province. The method used is descriptive analysis using qualitative approach. This study uses primary data sources obtained through interviews and secondary data sources obtained through online media. The results showed that the ability of the principal to implement the vision and mission in improving the quality of education in MAN 1 Tulang Bawang Barat can be seen from the behavior of the principal in carrying out the preparation of the school's vision and mission with a joint discussion, the creation of an education program guided by the quality standards of education, and promoting civility, as well as mobilizing school residents to participate in improving the quality of education. The ability of the principal to communicate effectively in improving the quality of education in MAN 1 Tulang Bawang Barat is reflected in the principal's behavior in cultivating a disciplined lifestyle and interacting directly with school residents and in problem solving through a system of discussions, meetings, or deliberations. then, the ability of the principal in developing academic and non-academic programs that can produce good quality for the school..
\end{abstract}

Keywords: Leadership Style, Head of Madrasah, Democratis and Transformational.

\begin{abstract}
Abstrak
Pengelolaan lembaga atau organisasi pendidikan adalab masalab yang sangat penting dalam dunia pendidikan. Sebab, suksesnya suatu lembaga pendidikan itu bergantung pada kepemimpinan kepala Madrasabnya. Penelitian ini bertujuan untuk mengetahui implementasi gaya kepemimpinan demokeratis dan transformasional kepala Madrasah di MAN 1 Tulang Bawang Barat provinsi Lampung. Metode yang digunakan adalah deskriptif analisis dengan menggunakan pendekatan kualitatif. Penelitian ini menggunakan sumber data primer yang diperoleh melalui wawancara dan sumber data sekunder yang diperoleh melalui media online. Hasil penelitian menunjuk.kan bahwa Kemampuan kepala sekolah mengimplementasikan visi dan misi dalam meningkatkan mutu pendidikan di MAN 1 Tulang Bawang Barat dapat dilihat dari perilaku kepala sekolah dalam melaksanakan penyusunan visi dan misi sekolah dengan diskusi bersama, pembuatan program pendidikan dengan berpedoman pada standar mutu pendidikan, dan mengedepankan keteladanan, serta menggerakekan warga sekolab untuk ikut serta dalam meningkatkan mutu pendidikan. Kemampuan kepala sekolah melakukan komunikasi efektif dalam meningkatkan mutu pendidikan di MAN 1 Tulang Bawang Barat tercermin dari perilaku kepala sekolah dalam membudayakan pola hidup disiplin dan berinteraksi secara langsung dengan warga sekolah serta dalam penyelesaian masalah dilakukan melalui sistem diskusi, rapat, atau musyawarah. kemudian, kemampuan kepala sekolah dalam mengembangkan program-program akademik maupun non akademik yang dapat menghasilkan mutu yang baik bagi sekolah.
\end{abstract}

Kata Kunci: Gaya Kepemimpinan, Kepala Madrasah, Demokratis dan Transformasional 


\section{INTRODUCTION}

The management of educational institutions or organizations is a very important issue in the world of education. The success of the learning process in an educational institution becomes a determinant for the quality of education. An educational institution such as Madrasah desperately needs a madrasah head who can lead and manage madrasahs well and professionally (Prayoga, Muharomah, dan Sutarti 2019, 34). Therefore, the ability of leaders is very important to run the organization. A good leader, he argues, can work in any form of structure (Krisnanda dan Surya 2019, hlm. 70.) According to wiyono, the leadership of madrasah head is one of the decisive aspects for the success of an education in Madrasah(Wiyono, B. B. 2017). Because, the head of madrasah here has a very important role in improving the development of madrasah routinely (Yang, $Y$ 2014). As the leader of the education unit, the head of madrasah is central to the successful progress of an educational institution. Because, the success of a madrasah depends on the leadership of the head of the madrasah. Thus, the leader of an institution is required to be able to move its institution in achieving an expected goal.

The leadership of madrasah heads is also a determinant for all resources in madrasahs, especially in resources that include teachers and other employees. Because, the importance of the existence of a sanhat leader is related to leadership functions and managerial functions, such as: as a mobilizer, vision and influence, planning, implementation, monitoring and even evaluation (Y. T. S. Aisyah 2016, 1033). The head of madrasah as a person who was chosen to be a leader, educator, administrator, and supervisor, became a full hope that the head of the madrasah could manage his educational institution towards promising developments with a good future. The head of madrasah must be able to make changes towards a better future in global life. The success of an educational institution is the success of the head of madrasah, but it also depends heavily on the type and style of leadership.

The leadership style is a typical way or behavior owned and carried out by a leader in leading his members or groups (Zuryati, Ar, dan Usman 2015, 41). As Hersey and Blanchard have said that the leadership style can be done effectively depending on the maturity, for him to grow up here does not mean about age or being able to control his emotional wellbeing, but rather about how he has the desire to have achievements, is willing to assume responsibility, and has the ability and experience associated with his duties (Wahyudi 2012, 123). Then if in the world of education, the leadership style of 
education is defined as a way or action of an educational institution leader in managing, directing, organizing, and guiding the staff of the board of teachers and other employees to be willing to cooperate in achieving educational goals (Zuryati, Ar, dan Usman 2015, 41).

Therefore, in managing an educational institution, a madrasah head is certainly in desperate need of a leadership style, one of which is the democratic leadership style and transformational leadership style. According to Woods (WOODS 2004), the democratic leadership style is to influence the ability of others to work together in achieving the goals that have been achieved then determine some programs that will be implemented jointly, namely between superiors and subordinates (Laliasa, Nur, dan Tambunan 2018). Democratic leadership is also an instilling and challenging attitude (WOODS 2004). In simple terms transformational leadership can be interpreted as the process to transform and transform an individual in order to change and improve himself, which involves motive and fulfillment of needs and appreciation for subordinates (Eko Purnomo, Herlina JR Saragih 2016, 12).

The indicator used to assess the democratic leadership style is to direct its subordinates to use their cognitive abilities and reasoning to solve a problem, then direct to take advantage of its innovation and creativity when carrying out both its duties and obligations, and the leadership and members participate with each other when making decisions or when solving a problem, then the relationship between the leader and the subordinate must be well established (Rosiana Natalia Djunaedi, Lenny Gunawan 2018, 43). this is in accordance with Anderson's statement quoted by Sanghan Choi, defining that a democratic leader is a leader who in making narrowness is always done with its members or deliberation (Choi 2007, 246).

Then, transformational leadership is one type of leadership that is very suitable to face the era of globalization. Based on recent reviews, transformational leadership theory is the most widely explored and discussed leadership theory in a new generation (Berkovich 2016, 610). Some understanding of transformational leadership has been explained, one of which is explained by a team of lecturers of the Indonesian Education Authority. $\mathrm{He}$ explains: "Transformational leadership is formed on two words, namely leadership and transformational (change). The term "conversion" means to change something that already exists into a different form, such as realizing a vision that is expected to become a reality (Tim Dosen Administrasi Pendidikan Uiversitas Pendidikan Indonesia 2012, 125). Although 
transformational leadership is known for its success and attention as one of the outstanding leadership theories, some researchers have observed a special relationship between transformational leadership theory and team performance. Which is the ideal inspirational influence or motivation, intellectual stimulation and individual considerations can result in a shared vision, commitment between teams, an empowering environment (Dionne dkk. 2004).

One of the techniques of tansformonal leaders is to maintain the motivation of followers through ceremonies, rituals and other cultural symbolism. Small changes get big results, pumping significant changes towards them is a real indicator of progress. Overall, they pay attention between actions that result in progress and the mental state of their followers. In addition to other leadership theory approaches, transformational leadership is more person-oriented and believes that success will come first or last through consistent and sustainable commitment (Siswoyo Haryono 2015, 119). This transformational leadership is also more focused on the process of building a commitment to the goals of an organization.

As samino stated that this democratic leadership style is considered the most ideal style by various circles.
Because, the head of Madrasah who has a democratic leadership style is considered to have various advantages in developing Madrasah (Ghozali dan Milansari 2019, 206). Then in a transformational leadership style, a madrasah head always makes new trobosans to improve the quality of madrasah every year. If a leader applies this transformational leadership style, it is expected that the leader already has broad insights in the future to try to make improvements in developing an organization for the future by making the condition of madrasah organization so that it can be better so that it can produce a good organizational outcome as well.

Based on the explanation above, we can know that the leadership style of madrasah head is democratic and transformational, each has an advantage in the development of educational institutions. However, in reality there are still problems regarding madrasah heads who do not know how to use their authority to manage madrasahs that they lead (Sofo, F. Fitzgerald, R. Jawas, U. 2012). This condition reveals that the ability of madrasah heads in managing their institutions is still considered weak. In education, the leadership of madrasah heads here becomes something crucial that has a significant influence between the leadership ability of madrasah heads and their effectiveness in an educational 
institution (Moorosi dan Bantwini 2016).

On this basis, the researchers wanted to find out how to implement the democratic and transformational leadership style of madrasah head in MAN 1 Tulang Bawang Barat.

\section{RESEARCH METHODS}

This research uses descriptive qualitative research method. With data collection techniques in the form of observations, interviews, literature studies, and internet media. This study used primary data sources obtained through interviews and secondary data sources obtained through online media. Data analysis is done by using several steps including data collection, data reduction, data display, and conclusion drawing. The informant in the study was the head of madrasah. For the location of the research was conducted in MAN 1 Tulang Bawang Barat which is located at Jalan Merdeka No. 1 RT 05 RW 03, Mulya Kencana, Tulang Bawang Tengah District, Tulang Bawang Barat Regency, Lampung Province. This research aims to find out the implementation of democratic and transformational leadership style of madrasah head in MAN 1 Tulang Bawang Barat.

\section{RESULTS AND DISCUSSIONS}

Biography of The Head of Madrasah MAN 1 Tulang Bawang Barat

H. Imam Kahfi, M.Pd.I is the full name of the head of MAN 1 Tulang Bawang Barat. He was born in Trenggalek on March 12, 1966. Currently he lives in the village of Tegal Mukti District Of The Great State of Way Kanan Regency of Lampung Province. He currently serves as Head of MAN 1 Tulang Bawang Barat. Based on the observations that have been made, he is the head of madrasah who is authoritative, committed, hardworking, and responsible, and highly appreciates opinions, advice and always receives advice from employees and staff of madrasah employees in a forum of deliberation to reach a consensus. Not only that, not infrequently he also always motivates staff and employees and cooperates in carrying out the mandate in order to achieve optimal and meaningful organizational resources in accordance with the targets that have been determined. In carrying out his duties and obligations he applies the nature of kinship, owning and raising each other with fellow staff teachers and other employees, so as to bring about the cohesiveness between each other in advancing Madrasah achieves the goal.

He has a history of education that was started with a basic education at MIS Hidayatul Mubtadin Gunung Balak 
graduated in 1980, then continued his junior high school at Mts Persiapan Negeri Brajasakti Way Jepara graduated in 1983, and continued pgan metro high school graduated in 1986, then he continued his undergraduate education at STAI Ma'arif Metro tarbiyah faculty majoring in PAI (Islamic Religious Education) graduated in 2003. And lastly he continued his master's degree majoring in MPI (Islamic Education Management) at UIN Raden Intan Lampung and graduated in 2013 (Imam Kahfi 2016, 177).

As an educator, he has attended courses and trainings, namely: education and subtantif technical training to improve the competence of preparing scientific publications for scientific teachers in 2013 at the Palembang Religious Training Center. He also participated in a workshop on performance assessment of Madrasah teachers in Bandar Lampung in 2012, then a National seminar to build the character of the nation based on Islamic religious education in 2011 in Bandar Lampung, English Language Teaching Workshop by Aibeb Education Partnership with Indonesia and Kangaroo 2013 in Bandar Lampung, Colocium between nations paradigm of Islamic thought in Southeast Asia in 2013 on the campus of IKIP 3 Taman Gelora Kuantan Pahang Darul Makmur Malaysia , scouting orientation courses for kamabigus head of Madrasah seprovinsi Lampung in 2013 in Bandar Lampung, workshop mentoring the implementation of curriculum 2013 in 2014 in Bandar Lampung, and subtantif training of madrasah head and additional duties in Bandiklat Ciputat Jakarta in 2015, and many others (Imam Kahfi 2016, 178).

Prior to serving as head of MAN 1 Tulang Bawang Barat, he also served as head of Madrasah Ibtidaiyah Negeri Tegal Mukti Way Kanan district in 2008-2014, then served as head of MTs One Roof Tegal Mukti Way Kanan district in 20092012, and then served as head of MTsN 2 Way Kanan in 2014-2018. He also has a good history of achievements during his time as head of Madrasah. His achievements include: 2nd winner of Madrasah ibtidaiyah competition at Lampung provincial level in 2003, 2nd winner of PAI teacher competition with ibtidaiyah level in Lampung province in 2003, best participant in administration training of head of Madrasah Lampung province in 2013, and 1st winner of madrasah head competition with MTs level in Lampung province in 2015. Then he also achieved the achievement as the head of the best madrasah creative and innovative in Lampung province in 2020 (Imam Kahfi 2016, 179). 
Implementation of Democratic And Transformational Leadership Style of Madrasah Head in MAN 1 Tulang Bawang Barat

MAN 1 Tulang Bawang Barat is one of Madrasah Aliyah Negeri located in Tiyuh Mulya Kencana District Tulang Bawang Tengah Tulang Bawang Barat Lampung Province. Based on the results of interviews and data above, MAN 1 Tulang Bawang Barat has recorded quite a lot of achievements. Mr. H. Imam Kahfi as the Head of MAN 1 Tulang Bawang Barat, he was able to make changes and improve the quality of education gradually in accordance with its development. So MAN 1 Tulang Bawang Barat is now a madrasah that can be considered much more advanced than before. It is evident by the increasing number of new learners from year to year has changed significantly, this can be seen from the improvement of the quality of madrasah facilities and infrastructure that are increasingly advanced, can be seen from various excellent programs both academic and non-academic, and also seen from the various achievements that have been achieved by MAN 1 Tulang Bawang Barat.

The achievements that have been achieved by MAN 1 Tulang Bawang Barat both academic and non-academic both at the sub-district, district, city, and province levels, as follows:
Table 1. List of Achievements of MAN 1 Tulang Bawang Barat

\begin{tabular}{|c|c|c|c|}
\hline No & Name & Description & Years \\
\hline 1. & $\begin{array}{l}\text { David } \\
\text { Qomarifai }\end{array}$ & $\begin{array}{l}\text { Pramuka } \\
\text { National } \\
\text { Level (Asian } \\
\text { Scout } \\
\text { Jambore } \\
\text { Thailand) }\end{array}$ & 2019 \\
\hline 2. & $\begin{array}{l}\text { Mustakim } \\
\text { Hidayat }\end{array}$ & $\begin{array}{l}\text { Paskib } \\
\text { District } \\
\text { Level }\end{array}$ & 2019 \\
\hline 3. & Saputri & $\begin{array}{l}\text { Paskib } \\
\text { District } \\
\text { Level }\end{array}$ & 2019 \\
\hline 4. & $\begin{array}{l}\text { Muhamma } \\
\text { d Nur } \\
\text { Safik }\end{array}$ & $\begin{array}{l}\text { Juara } 3 \\
\text { Kejurda } \\
\text { Atletik } \\
\text { Provincial } \\
\text { Level }\end{array}$ & 2019 \\
\hline 5. & $\begin{array}{l}\text { Art } \\
\text { performan } \\
\text { ce } \\
\text { Champion } \\
3\end{array}$ & $\begin{array}{l}\text { Saka Bayang } \\
\text { Kara Second } \\
\text { Branch } \\
\text { Level } \\
\text { Tulang } \\
\text { Bawang }\end{array}$ & 2019 \\
\hline 6. & $\begin{array}{l}\text { The } \\
\text { Neatness } \\
\text { of The } \\
\text { Hope } \\
\text { Champion } \\
\text { Tent }\end{array}$ & $\begin{array}{l}\text { Saka Bayang } \\
\text { Kara Second } \\
\text { Branch } \\
\text { Level } \\
\text { Tulang } \\
\text { Bawang }\end{array}$ & 2019 \\
\hline 7. & $\begin{array}{l}\text { 3rd Men's } \\
\text { Semapur } \\
\text { Champion } \\
3\end{array}$ & $\begin{array}{l}\text { GPTP Ke } 5 \\
\text { Kwarcab }\end{array}$ & 2019 \\
\hline 8. & $\begin{array}{l}\text { Faisal Ega } \\
\text { Pratama }\end{array}$ & $\begin{array}{l}\text { Champion } 3 \\
\text { Fisika } \\
\text { Integrated } \\
\text { KSM } \\
\text { District } \\
\text { Level }\end{array}$ & 2019 \\
\hline 9. & $\begin{array}{l}\text { Elsa } \\
\text { Rosdinana } \\
\text { Harahap }\end{array}$ & $\begin{array}{l}\text { Champion } 3 \\
\text { Geografi } \\
\text { Integrated } \\
\text { KSM } \\
\text { District } \\
\text { Level }\end{array}$ & 2019 \\
\hline 10. & $\begin{array}{l}\text { Nur } \\
\text { Fadilah } \\
\text { Harahap }\end{array}$ & $\begin{array}{l}\text { Champion } 2 \\
\text { Ekonomi }\end{array}$ & 2019 \\
\hline 11. & $\begin{array}{l}\text { Volly } \\
\text { Women's }\end{array}$ & $\begin{array}{l}\text { Madrasah } \\
\text { Level }\end{array}$ & 2020 \\
\hline
\end{tabular}




\begin{tabular}{|c|c|c|c|}
\hline & Ball 1st & Regency & \\
\hline & Place & Scope & \\
\hline \multirow[t]{4}{*}{12.} & Volly & Madrasah & 2020 \\
\hline & Men's Ball & Level & \\
\hline & 2nd Place & Regency & \\
\hline & & Scope & \\
\hline \multirow[t]{4}{*}{13.} & Futsal 2nd & Madrasah & 2020 \\
\hline & place & Level & \\
\hline & & Regency & \\
\hline & & Scope & \\
\hline \multirow[t]{4}{*}{14.} & badminton & Madrasah & 2020 \\
\hline & women's & Level & \\
\hline & champion & Regency & \\
\hline & 2nd & Scope & \\
\hline \multirow[t]{4}{*}{15.} & Athletics & Madrasah & 2020 \\
\hline & 100.m 1st, & Level & \\
\hline & 2nd and & Regency & \\
\hline & 3rd Place & Scope & \\
\hline \multirow[t]{4}{*}{16.} & Men's & Madrasah & 2020 \\
\hline & Table & Level & \\
\hline & Tennis & Regency & \\
\hline & Champion & Scope & \\
\hline \multirow[t]{4}{*}{17.} & Women's & Madrasah & 2020 \\
\hline & Table & Level & \\
\hline & Tennis & Regency & \\
\hline & Champion & Scope & \\
\hline \multirow[t]{7}{*}{18.} & Maharani & Champion & 2020 \\
\hline & Putri & of Hope & \\
\hline & Azzahra & D'ai Muda & \\
\hline & & Kanwil & \\
\hline & & Kemenag & \\
\hline & & Lampung & \\
\hline & & Province & \\
\hline
\end{tabular}

MAN 1 Bone Onion West can be said to have increased, this can be seen from year to year the number of learners is increasing significantly as follows:

Table 2. Data of MAN 1 Tulang Bawang Barat Year 2017-2020 students

\begin{tabular}{ccccc}
\hline Years & Class & Rombel & Amount & $\begin{array}{c}\text { Total } \\
\text { Number }\end{array}$ \\
\hline $\mathbf{2 0 1 7}$ & X & 2 & 51 & 134 \\
& XI & 2 & 40 & \\
& XII & 2 & 43 & \\
$\mathbf{2 0 1 8}$ & X & 2 & 53 & 149 \\
& XI & 2 & 54 & \\
& XII & 2 & 42 & \\
\hline
\end{tabular}

\begin{tabular}{ccccc}
\hline 2019 & X & 3 & 88 & 203 \\
& XI & 3 & 59 & \\
& XII & 2 & 56 & \\
$\mathbf{2 0 2 0}$ & X & 4 & 98 & 252 \\
& XI & 3 & 88 & \\
& XII & 2 & 66 & \\
\hline
\end{tabular}

Thus, the above information shows that the leadership of madrasah head has carried out its duties and obligations well. This is certainly inseparable from how he leads and manages madrasahs. Because, the head of madrasah can be said to be successful if he is able to carry out his role as a person given the responsibility to lead and can understand the existence of madrasahnya as a complex and unique institution or organization. Maxwell said that, a leader must be able to make others believe first in his leader only then believe in his vision. Because the most important cornerstone of leadership is trust. This indicates that a madrasah will succeed in its vision and mission and objectives if the teachers, staff and other employees believe in the leadership of the head of the Madrasah (Zuryati, Ar, dan Usman 2015, 40).

Being a leader in an educational institution, the head of madrasah has a function in its role including: (1) the head of madrasah as administrator in education, meaning that the headmaster must be able to improve the quality of madrasah and the headmaster must be able to adequately, improve, and develop madrasah facilities, (2) the head of madrasah as supervision in 
education, meaning that the efforts of the madrasah head in improving the quality of madrasahnya can be done by improving the quality of the staff of the board of teachers and all madrasah employees first, namely by means of meeting, observation of classrooms, and so on (S. Aisyah dan Takdir 2017, 120).

In addition, Wahjosumidjo also said that the duty of the head of Madrasah as a leader in an educational institution is to mobilize all its members who have a function in carrying out their duties and obligations. The head of madrasah should also give appreciation to the teacher for his hard work so that the teacher can be more eager to serve. Then the head of madrasah must be able to maintain and create good relations to teachers and other staff employees in order to establish a harmonious and pleasant situation. And the head of madrasah is expected not to impose the will of the teachers in taking or giving decisions which decisions should remain in accordance with the mutual agreement (Wahjosumidjo 2013, 83).

Based on the results of the research, the implementation of the democratic and transformational leadership style of the head of MAN 1 Tulang Bawang Barat was seen in the implementation of madrasah head socialization of madrasah vision and mission and objectives in various ways, such as: done by making pamphlets installed in school environments and various suburbs. The head of madrasah is also able to solve all problems that arise. The head of madrasah was also able to overcome the behavior of the teachers. And the head of madrasah was able to attract attention for teachers to be able to carry out their duties and obligations effectively that these tasks and obligations are very necessary to do. Based on the results of the interview, in the decision making of the head of madrasah do it by prioritizing deliberation first. So that the head of madrasah does not take decisions unilaterally. All are conducted on the basis of deliberation, meetings, coordination with the teachers' board.

Then based on the interview results, in improving the quality of Madrasah effectively, the head of Madrasah has held academic and non-academic flagship programs, which are categorized as sports, organizations, arts and culture, among others, table tennis, badminton, basketball, volly ball, football, pencak silat, futsal, athletics, scouting, dance art, performing arts, music arts, KIR, UKS, PMR, student council, paskibra, skill, computer, arabic club, english club, art, tahfidz alqur'an, MTQ, syarhil Qur'an, ilmiyah writing, hadroh, sewing/tataboga, electronics, freshwater fishery, da'i/da'iyahh, journalism. There have been 
many non-academic achievements that madrasah has achieved, both city / district, provincial, national level.

This is called democratic leadership. Ducan explained that the head of madrasah who has this type of democratic leadership in his leadership is not used as a dictator, malainkan as the head of madrasah that is in the middle of his subordinates. The point is that the head of madrasah here who has democratic attitude is done by discussing first to his subordinates about a problem. This shows a leader's attitude to transformational leadership because it means to consider the needs led by needs above personal needs..

Furthermore, in its implementation, the head of Madrasah MAN 1 Tulang Bawang Barat explained his leadership behavior, especially transformational leadership in accordance with the opinion of Bass and Avolio, namely the head of Madrasah as a transformative leader has shown a motivating figure, inspiration, and intellectual stimulation. This is very influential in this leadership behavior which is done through behavior, interaction with subordinates and participation for madrasah activities (Siska Cahya, Roesminingsih 2014, 59). Based on the results of the study, the head of MAN 1 Tulang Bawang Barat carried out the implementation of the three components by providing motivation to himself and also providing motivation to his subordinates. The motivation for the head of madrasah itself is to be eager to work, must be disciplined, able to provide good tauladan, do good and be able to solve problems and even eager to continue learning in order to give the best and be the best as the head of Madrasah.

Then for the motivation given to his subordinates, shown by delegation of tasks, paying attention to the needs, creations, innovations of his subordinates even doing academic and non-academic motivation, motivation of work achievement in the form of material or non material to improve the quality of educators and education in MAN 1 Tulang Bawang Barat. Head of MAN 1 Tulang Bawang Barat also made a development by conducting coaching programs and also training. That is one of them with coaching in applying discipline, especially selfdiscipline. This is done because a leader is required to assist his subordinates in developing and familiarizing a disciplined lifestyle in improving standards of conduct in accordance with the rules.

In this transformational leadership, it will have a positive influence on the relationship between the leader and the madrasahnya citizens. Because with this leadership the madrasahnya citizens will be able to feel awe, pride, loyalty and respect to the head of madrasahnya. It can even 
give rise to self-motivation to carry out work with better results. The head of madrasah is an ideal figure who serves as a role model for the staff of teachers and their students. The head of madrasah is a trusted and respected figure even able to make decisions that are in the best interest of Madrasah (Prayoga 2019, 39.).

However, the headmaster's innovative, independent and professional attitude towards educational leadership will certainly encourage teachers to imitate the headmaster's behaviour. They will be more passionate, high fighting spirit, and active in the learning process which is their professional responsibility. Therefore, the culture and atmosphere of the school conducive to the implementation of quality learning processes in schools will be created and boil down to the high student achievement expected by all stakeholders in the education system.

\section{CONCLUSION}

Based on the results of the discussion above, it can be concluded that the democratic and transformational leadership style of man 1 Tulang Bawang Barat is evidenced by the efforts made by the head of Madrasah in improving the quality of MAN 1 Tulang Bawang Barat, among others by socializing the vision and mission and objectives of Madrasah in various ways, conducting excellent programs both academic and non- academic, motivating its subordinates by paying attention to the needs, creation, innovation, even doing academic and nonacademic motivation, motivation of work performance in the form of material or non-material to improve the quality of educators and educational personnel, then give awards or rewards for educators and outstanding learners, then the head of madrasah also conducts coaching programs and also training to his subordinates in developing and familiarizing the disciplined lifestyle. Therefore, as the head of the madrasah must have a significant influence on the culture of the organization that can create more followers, commit, improve performance and build a solid team, creative and innovative ideas emerge and realize the vision, mission and objectives of the madrasah will run effectively and efficiently.

\section{REFERENCES}

Aisyah, Sitti, dan Soltan Takdir. 2017. "Implementasi Gaya Kepemimpinan Situasional Kepala Sekolah Di Smp Negeri 1 Wamena Kabupaten Jayawijaya." Jurnal Kepemimpinan dan Pengurusan Sekolah 2 (2): 119-32.

Aisyah, Yuli Triana St. 2016. “Gaya Kepemimpinan Kepala Sekolah Sma Di Banjarmasin." Jurnal Pendidikan Kewarganegaraan 6 (2): 1055-62. 
Berkovich, Izhak. 2016. "School leaders and transformational leadership theory: time to part ways?" Journal of Educational Administration 54 (5): 609-22.

Choi, Sanghan. 2007. "Democratic Leadership: The Lessons of Exemplary Models for Democratic Governance" 2: 20.

Dionne, Shelley D., Leanne E. Atwater, William D. Spangler, dan Francis J. Yammarino. 2004. "Transformational leadership and team performance." Journal of Organizational Change Management 17 (2): 177-93.

Eko Purnomo, Herlina JR Saragih. 2016. Teori Kepemimpinan Dalam Organisasi. Jakarta: Yayasan Nusantara Bangun Jaya.

Ghozali, Alif Lutfi, dan Umi Alimah Milansari. 2019. “Kepemimpinan Demokratis Kepala Sekolah di SD Muhammadiyah Program Khusus Andong," Januari.

Imam Kahfi. 2016. Meningkatkan Kompetensi

Profesional Guru Melalui Gaya Kepemimpinan Transformasional. Palembang: Limas.

Krisnanda, Putu Harry, dan Ida Bagus Ketut Surya. 2019. "Effect of Emotional and Spiritual
Intelligence on Transformational Leadership and Impact on Employee Performance.” International Research Journal of Management, IT and Social Sciences 6 (3): 70-82.

Laliasa, Gunawan, Muh Nur, dan Rince Tambunan. 2018. "Pengaruh Gaya Kepemimpinan Demokratis, Lingkungan Kerja Dan Motivasi Kerja Terhadap Kinerja Pegawai Dinas Perkebunan Dan Hortikultura Provinsi Sulawesi Tenggara." Sigma: Journal of Economic and Business 1 (1): 83-103.

Moorosi, Pontŝo, dan Bongani D. Bantwini. 2016. "School District Leadership Styles and School Improvement: Evidence from Selected School Principals in the Eastern Cape Province." South African Journal of Education 36 (4): 19.

Prayoga, Ari. 2019. "Implementasi Kepemimpinan Transformatif Kepala Madrasah Aliyah Ma'arif Cilageni Kadungora." Attaqwa: Jurnal Ilmu Pendidikan Islam 15 (1).

Prayoga, Ari, Rismaya Muharomah, dan Sutarti Sutarti. 2019. "Implementasi Kepemimpinan Transformatif Kepala Madrasah Aliyah Ma'arif Cilageni Kadungora." Attaqwa: 
Jurnal Ilmu Pendidikan Islam 15 (1): 33-44.

Rosiana Natalia Djunaedi, Lenny Gunawan. 2018. "Pengaruh Gaya Kepemimpinan Demokratis Terhadap Kinerja Karyawan | Performa" 3 (3).

Siska Cahya, Roesminingsih, Erny. 2014. "Implementasi Kepemimpinan Transformasional Di Sd Muhammadiyah 4 Surabaya" 3 (3): 10.

Siswoyo Haryono. 2015. Intisari Teori Kepemimpinan. Jawa Barat: PT Intermedia Personalia Utama.

Sofo, F. Fitzgerald, R. Jawas, U. 2012. "Instructional Leadership in Indonesian School reform: Overcoming the problems to move forwad. School Leadership and Management” 32 (5): 503-22.

Tim Dosen Administrasi Pendidikan Uiversitas Pendidikan Indonesia. 2012. Manajemen Pendidikan. Bandung: Alfabeta.

Wahjosumidjo. 2013. Kepemimpinan Kepala Sekolab: Tinjauan Teoretik dan Permasalahannya. 9 ed. Jakarta: PT Raja Grafindo Persada.

Wahyudi. 2012. Kepemimpian Kepala Sekolah dalam Organisasi Pembelajaran. Bandung: Alfabeta.
Wiyono, B. B. 2017. "The Effect of Selfevaluation on the Principals" Transformational Leadership, Teachers Work Motivation, Teamwork Effectiveness, and School Improvement. International Journal of Leadership in Education,"1-21.

WOODS, PHILIP A. 2004. "Democratic leadership: drawing distinctions with distributed leadership." International Journal of Leadership in Education 7 (1): 3-26.

Yang, Y. 2014. "Principals Transformational Leadership in School Improvement." International Journal of Educational Management. 28 (3): 279-288.

Zuryati, Djailani Ar, dan Nasir Usman. 2015. "Gaya Kepemimpinan Kepala Sekolah Dalam Meningkatkan Kinerja Guru Pada Sdn 7 Muara Dua Lhoksuemawe." Jurnal Administrasi Pendidikan Program Pascasarjana Unsyiab 3 (2): 74105 . 